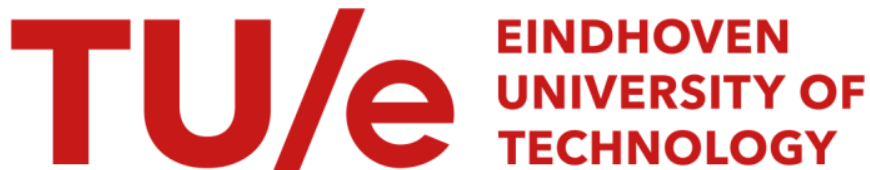

\section{Sulfidability and HDS activity of Co-Mo/Al2O3 catalysts}

\section{Citation for published version (APA):}

Scheffer, B., Oers, van, E. M., Arnoldy, P., Beer, de, V. H. J., \& Moulijn, J. A. (1986). Sulfidability and HDS activity of Co-Mo/Al2O3 catalysts. Applied Catalysis, 25(1), 303-311. https://doi.org/10.1016/S01669834(00)81248-8

DOI:

10.1016/S0166-9834(00)81248-8

Document status and date:

Published: 01/01/1986

\section{Document Version:}

Publisher's PDF, also known as Version of Record (includes final page, issue and volume numbers)

\section{Please check the document version of this publication:}

- A submitted manuscript is the version of the article upon submission and before peer-review. There can be important differences between the submitted version and the official published version of record. People interested in the research are advised to contact the author for the final version of the publication, or visit the $\mathrm{DOI}$ to the publisher's website.

- The final author version and the galley proof are versions of the publication after peer review.

- The final published version features the final layout of the paper including the volume, issue and page numbers.

Link to publication

\section{General rights}

Copyright and moral rights for the publications made accessible in the public portal are retained by the authors and/or other copyright owners and it is a condition of accessing publications that users recognise and abide by the legal requirements associated with these rights.

- Users may download and print one copy of any publication from the public portal for the purpose of private study or research.

- You may not further distribute the material or use it for any profit-making activity or commercial gain

- You may freely distribute the URL identifying the publication in the public portal.

If the publication is distributed under the terms of Article 25fa of the Dutch Copyright Act, indicated by the "Taverne" license above, please follow below link for the End User Agreement:

www.tue.nl/taverne

Take down policy

If you believe that this document breaches copyright please contact us at:

openaccess@tue.nl

providing details and we will investigate your claim. 
8. Scheffer, E.M. van Oers ${ }^{1}$, P. Arnoldy2 , V.H.J. de Beer ${ }^{1}$ and J.A. Moulijn Institute of Chemical Technology, University of Amsterdam

1) Lab. of Inorganic Chemistry and Catalysis, Eindhoven University of Technology

2) present address: Konink 1 ijke/Snell Laboratory, Amsterdam

\section{ABSTRACT}

A series of $\mathrm{Co}-\mathrm{Mo}_{\mathrm{O}} / \mathrm{Al}_{2} \mathrm{O}_{3}$ catalysts were investigated using Temperature-Programmed Sulfiding and HDS activity measurements. The effect of changing the cobalt content and the temperature of calcination on sulfidability, catalyst structure and thiophene HDS activity was studied in detail.

It is found that the effect on the HDS activity of higher temperatures of calcination depends on the Co content: at low Co content the activity drops sharply, for intermediate co loadings the decline is not as pronounced, while at high co contents an increase in HDS activity is found when the temperature of calcination is raised above $785 \mathrm{~K}$.

The typical "synergistic" maximum observed when HDS activity is plotted versus co content (or Co/Mo ratio) does not occur when catalysts are calcined above $785 \mathrm{~K}$. Instead HDS activity rises monotonously with an increase in Co content.

At least five $\mathrm{Co}_{\mathrm{S}}$ species can be present in sulfided $\mathrm{Co}-\mathrm{MO}_{\mathrm{O}} / \mathrm{Al}_{2} \mathrm{O}_{3}$ catalysts but HDS activity can mainly be attributed in all catalysts to one particular phase which contains sulfided $M_{0}$ and $C_{0}$. After calcination at $1125 \mathrm{~K}$ the activity is increased because the interaction between the active phase and the support has weakened.

\section{INTRODUCTION}

$\mathrm{Co}-\mathrm{Mo} / \mathrm{Al}_{2} \mathrm{O}_{3}$ catalysts are widely used commercially as hydrotreating catalysts and they continue to be the subject of much research. Knowledge of the influence of metal content and preparation conditions on the structure of $\mathrm{Mo}_{0} / \mathrm{Al}_{2} \mathrm{O}_{3}$ [1-5] and $\mathrm{Co} / \mathrm{Al}_{2} \mathrm{O}_{3}$ [5-8] catalysts, both in the sulfided state and as oxidic precursor, can contribute to a better understanding of the parameters which control the structure of $\mathrm{Co}-\mathrm{Mo} / \mathrm{AT}_{2} \mathrm{O}_{3}$ catalysts.

The importance of $\mathrm{CO}$ in sulfided $\mathrm{CO}-\mathrm{Mo}_{\mathrm{O}} / \mathrm{Ai}_{2} \mathrm{O}_{3}$ catalysts is demonstrated by the observation that $C_{0}$ can be almost as active a catalyst as Mo when it is not supported $[13,29]$, or even more active on a carbon support, thus raising the question whether $\mathrm{CO}_{-} \mathrm{MO}_{\mathrm{O}} / \mathrm{Al}_{2} \mathrm{O}_{3}$ catalysts should be considered as co catalysts promoted, or supported, by Mo $[6,14,27]$. For the sulfided $\mathrm{Co}-\mathrm{Mo}_{\mathrm{A}} \mathrm{A}_{2} \mathrm{O}_{3}$ catalyst the 
CoMos model [15] has been applied with much success. In this model a high HDS activity is ascribed to sites which consist of sulfided Co on the edges of $\mathrm{MoS}_{2}$ crystallites ("CoMos").

However, it is not quite clear how the composition of the oxidic catalysts and the preparation conditions affect the amounts and activities of sulfided species. The relative abundance of co-containing species is very sensitive to these parameters $[6,7,8,16]$ and since high HDS activity is believed to be connected to the presence of a sulfided $C_{0}$ species it is of importance to know how the composition and preparation of the oxidic $\mathrm{Co}-\mathrm{Mo}_{\mathrm{O}} / \mathrm{Al}_{2} \mathrm{O}_{3}$ catalyst affect the sulfidability of $\mathrm{Co}$ and the abundance of different $\mathrm{Co}$ species in the sulfided $\mathrm{Co}-\mathrm{Mo} / \mathrm{Al}_{2} \mathrm{O}_{3}$ catalyst.

To exclude effects caused by the heterogeneity of the Mo monolayer $[1,2]$ we have fixed the Mo content of the catalysts. The co content and temperature of calcination were varied over a wide range. Since these same catalysts have been subjected to XRD, TPS [17], TPR and UV/VIS [18] studies, a detailed description of the relationships between the oxidic- and the sulfided catalysts, and HDS activity is possible.

\section{EXPERIMENTAL}

\section{Catalyst Preparation}

Catalysts were prepared by pore volume impregnation of a Ketjen High-Purity $y-\mathrm{Al}_{2} \mathrm{O}_{3}$, followed by drying and calcination. Mo was added first, and the catalyst was dried and calcined before addition of Co. The preparation of the catalysts is described in more detail elsewhere $[17,18]$. Co loadings in Co-Mo catalysts were $1.6 \%, 3.5 \%$ and $8.1 \%$ ( $\mathrm{g} \mathrm{CoO} / \mathrm{g} \mathrm{Al}_{2} \mathrm{O}_{3}$ ). Catalysts will be denoted by the number of metal atoms $/ \mathrm{nm}^{2} \mathrm{Al}_{2} \mathrm{O}_{3}$; e.g. $1.6 \% \mathrm{CoO}-9.9 \% \mathrm{MoO}_{3} / \mathrm{Al}_{2} \mathrm{O}_{3}$ as $\mathrm{Co}(.8) \mathrm{Mo}(2.5)$.

\section{Temperature-Programmed Sulfiding}

More information on the Temperature-Programmed Sulfiding (TPS) technique is given elsewhere [3,17]. At the beginning of the TPS experiment the sulfiding mixture $\left(3.3 \% \mathrm{H}_{2} \mathrm{~S}, 28.1 \% \mathrm{H}_{2}\right.$ and $\left.68.6 \% \mathrm{Ar}\right)$ is led through the reactor at ca $295 \mathrm{~K}$ and the composition of the gas leaving the reactor is monitored. When no more sulfiding or adsorption takes place at $295 \mathrm{~K}$ the temperature of the reactor is raised continuous $1 \mathrm{y}$ by $10 \mathrm{~K} / \mathrm{min}$ up to ca $1270 \mathrm{~K}$.

\section{HDS Activity}

Thiophene HOS was carried out in a flow microreactor operating at atmospheric pressure. Details of the equipment are given elsewhere [19]. The catalysts were sulfided in situ in a $10 \mathrm{~mol} \% \mathrm{H}_{2} \mathrm{~S} / \mathrm{H}_{2}$ mixture (flow rate ca $45.10^{-6} \mathrm{~mol} / \mathrm{s}$ ). The 
temperature was raised to $675 \mathrm{~K}$ and maintained for $2 \mathrm{~h}$. TPS results show that no more sulfiding takes place after this time. Then a $6.2 \mathrm{~mol} \%$ thiophene/ $\mathrm{H}_{2} \mathrm{mixture}$ was fed into the reactor at a total rate of $37.10^{-6} \mathrm{~mol} / \mathrm{s}$. After $2 \mathrm{~h}$ the HDS rate per gram of catalyst and Turn over Number (TON, defined per mol Co present) were calculated from thiophene conversion assuming the HDS reaction is first order in thiophene. When reactant and product inhibition were taken into account [20,21] essentially the same values were obtained.

\section{RESULTS}

Calcination at $1125 \mathrm{~K}$ of a Co(1.6)Mo(2.5) catalyst leads to a drop in surface area of more than a factor 4 . In a separate experiment calcination of the support at high temperature did not cause such drastic effects.

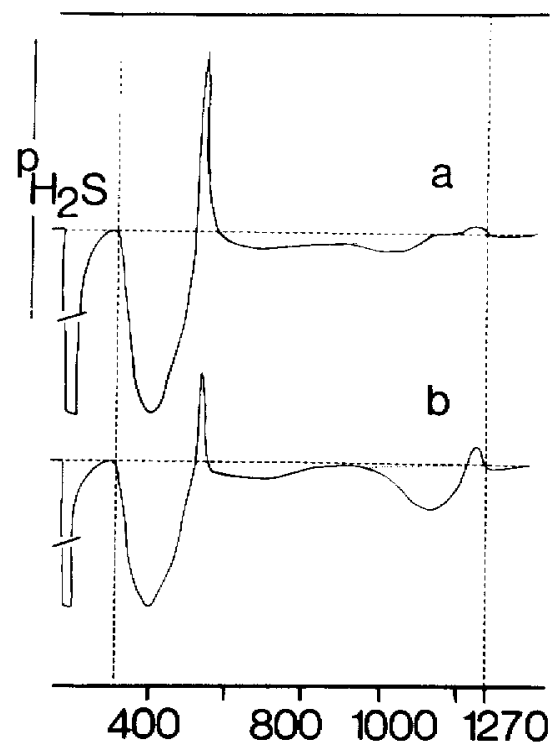

-temperature $(\mathrm{K})$ -

FIGURE 1 TPS patterns of $\mathrm{Co}(.8) \mathrm{Mo}(2.5) / \mathrm{Al}_{2} \mathrm{O}_{3}$ catalysts calcined at $895 \mathrm{~K}$ (a) and $1125 \mathrm{~K}$ (b).

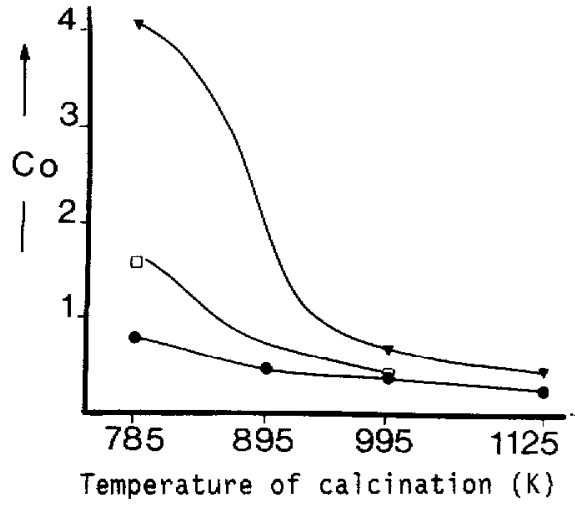

FIGURE 2 Amount of sulfided co (at $/ \mathrm{nm}^{2}$ ) in $\mathrm{Co}-\mathrm{Mo} / \mathrm{Al}_{2} \mathrm{O}_{3}$ catalysts. O $\mathrm{Co}(.8) \mathrm{Mo}(2.5), \square \mathrm{Co}(1.6) \mathrm{Mo}(2.5)$, $\nabla \operatorname{Co}(4.1) \operatorname{Mo}(2.5)$.

\section{Temperature-Programmed Sulfiding}

The TPS patterns of some $\mathrm{Co}-\mathrm{Mo} / \mathrm{Al}_{2} \mathrm{O}_{3}$ catalysts are shown in figure 1. For clarity only the $\mathrm{H}_{2} \mathrm{~S}$ pressures are plotted. The general features of these TPS patterns are the same as those reported previously in more detail [17]: 
- $\mathrm{H}_{2} \mathrm{~S}$ uptake at room temperature. The colour change from various shades of blue to brown-biack indicates that besides physical adsorption of $\mathrm{H}_{2} \mathrm{~S}$ also sulfiding takes place for most catalysts. Only the catalysts calcined at $1125 \mathrm{~K}$ remained blue at room temperature.

- $\mathrm{H}_{2} \mathrm{~S}$ uptake and $\mathrm{H}_{2} \mathrm{O}$ production up to ca $500 \mathrm{~K}$ caused by sulfiding of Mo and Co species via $0-S$ exchange. It has been shown that the effect of calcining on Mo sulfiding is small [17], however $\mathrm{H}_{2} \mathrm{~S}$ consumption is smaller for catalysts calcined at $1125 \mathrm{~K}$ because of loss of $\mathrm{MoO}_{3}$ during calcination

- $\mathrm{H}_{2} \mathrm{~S}$ production and $\mathrm{H}_{2}$ consumption at ca $500 \mathrm{~K}$ because of hydrogenation of $\mathrm{S}$. This is formed by the rupture of bonds between sulfur and Mo in oxy-sulfides [3]

- $\mathrm{H}_{2} \mathrm{~S}$ uptake and $\mathrm{H}_{2} \mathrm{O}$ production in a broad pattern from $500 \mathrm{~K}$ to $\mathrm{ca} 800 \mathrm{~K}$ caused by further sulfiding of mainly Mo

- $\mathrm{H}_{2} \mathrm{~S}$ uptake and $\mathrm{H}_{2} \mathrm{O}$ production at ca $1000 \mathrm{~K}$ from sulfiding of subsurface Co $\left(\mathrm{COAl}_{2} \mathrm{O}_{4}-\right.$ like) species [7]

- $\mathrm{H}_{2} \mathrm{~S}$ production and $\mathrm{H}_{2}$ consumption at ca $1200 \mathrm{~K}$ pointing to reduction of Co sulfides

Co sulfidability will be defined in this context as the fraction of co which is sulfidable below $675 \mathrm{~K}$ in a TPS experiment. Since both some Mo- and Co species are sulfidable below $675 \mathrm{~K}$ Co sulfiding can not be observed independently from Mo sulfiding in this temperature range. It has been found that for $\mathrm{Co} / \mathrm{Al}_{2} \mathrm{O}_{3}$ catalysts with different contents of $\mathrm{Co}_{\mathrm{O}}$ and temperatures of calcination the total consumption of $\mathrm{H}_{2} \mathrm{~S}$ in a TPS experiment up to $1270 \mathrm{~K}$ corresponds to a ratio of $.8 \mathrm{H}_{2} \mathrm{~S} / \mathrm{Co}_{0}$ [7] . Assuming the same ratio holds for $\mathrm{Co}$ in $\mathrm{Co}-\mathrm{Mo}_{\mathrm{A}} \mathrm{Al}_{2} \mathrm{O}_{3}$ catalysts sulfided up to $1270 \mathrm{~K}$, Co sulfidability is determined by subtracting the amount of $\mathrm{H}_{2} \mathrm{~S}$ used for sulfiding of $\mathrm{COAl}_{2} \mathrm{O}_{4}-1$ ike species at $\mathrm{Ca} 1000 \mathrm{~K}$ in a TPS experiment from the $\mathrm{H}_{2} \mathrm{~S}$ consumption which is calculated for complete sulfiding of $C_{0}$.

It can be seen in figure 2 that essentially all $C_{0}$ is sulfidable after calcination at $785 \mathrm{~K}$. Co sulfidabilty drops after calcination at $995 \mathrm{~K}$ and is still smaller after calcination at $1125 \mathrm{~K}$. After calcination at higher temperatures sulfidabilities converge to a value of $\mathrm{ca} .4 \mathrm{at} / \mathrm{nm}^{2}$ for all co contents.

\section{HDS Activity}

Mo/Al $2{ }_{3}$. The effect of a rise of the temperature of calcination up to $995 k$ is a small loss of activity whereas activity drops sharply after calcination at $1125 \mathrm{~K}$ (figure 3b). However, when loss of $\mathrm{MoO}_{3}$ during calcination is taken into account, the activity per mole Mo present is higher.

$\mathrm{Co} / \mathrm{Al}_{2} \mathrm{O}_{3}$. The catalysts with the lower loading of $\mathrm{Co}$ exhibit the highest turn-over numbers. A detailed account of the activity of $\mathrm{Co} / \mathrm{Al}_{2} \mathrm{O}_{3}$ catalysts will be given elsewhere [22]. 
Co-Mo/Al $2{ }_{2}-{ }_{3}$. Figure $3 a$ shows clearly the promoting effect of $\mathrm{Co}$ : the Co-Mo catalysts are up to 6 times more active than the Mo catalysts, and 10 times more active than the co catalysts. A typical synergistic curve is obtained which displays a maximum when the activity is plotted versus the Co content (or Co/Mo ratio) for the $\mathrm{Co}-\mathrm{Mo} / \mathrm{Al}_{2} \mathrm{O}_{3}$ catalysts calcined at $785 \mathrm{~K}$. However, the curves are quite different for the catalysts calcined at higher temperatures: no maximum in activity is found. Instead the activity rises monotonously with co content.

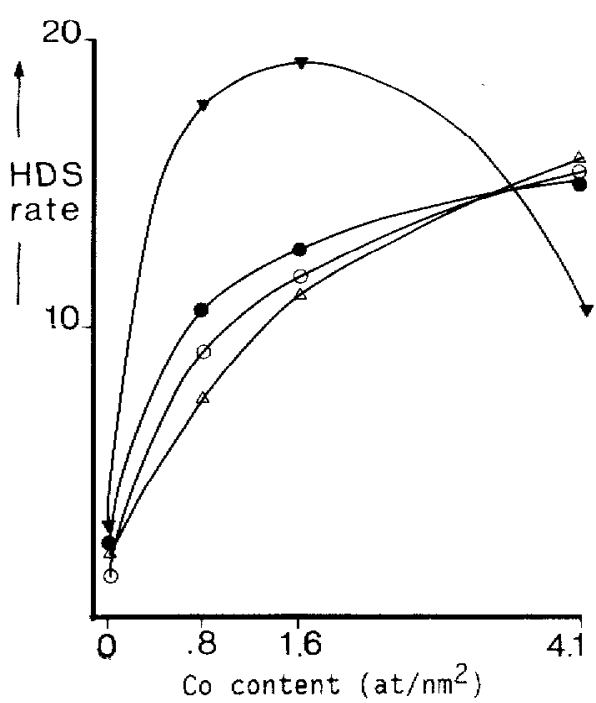

FIGURE 3a. Rate of thiophene HDS (mmol/g.h) of $\mathrm{Co}-\mathrm{Mo} / \mathrm{Al}_{2} \mathrm{O}_{3} \mathrm{Cata}-$ lysts calcined at $785 K(\nabla), 895 K$ $(\bullet), 995 \mathrm{~K}(\Delta)$ and $1125 \mathrm{~K}(\mathrm{O})$.

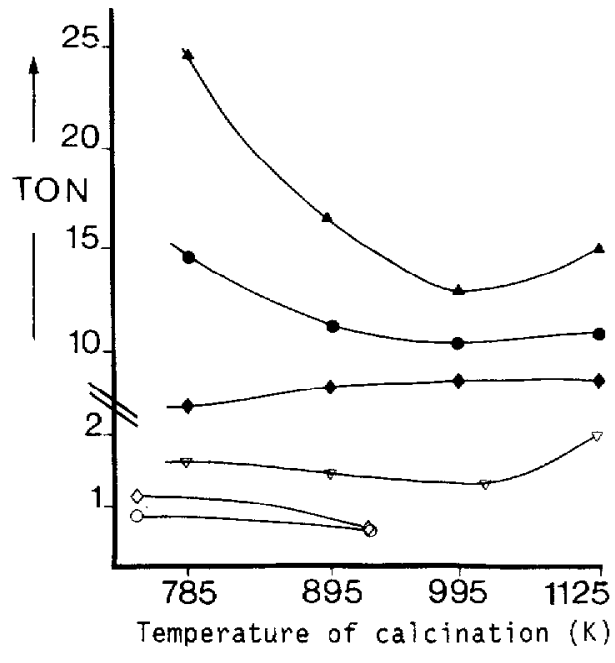

FIGURE 3b. HDS turn-over numbers $(\mathrm{mmol} / \mathrm{mol} . \mathrm{s})$ of $\mathrm{Co}-\mathrm{Mo} / \mathrm{Al}_{2} \mathrm{O}_{3}$ catalysts. $\Delta \mathrm{Co}(.8) \mathrm{Mo}(2.5)$, - Co(1.6)Mo(2.5), Co(4.1)Mo(2.5), $\nabla M_{0}(2.5), \diamond \operatorname{Co}(.8), O \operatorname{Co}(3.7)$.

Figure $3 b$ shows that there is a sharp drop in activity of the Co(.8)Mo(2.5) catalysts as the temperature of calcination is raised from 785 to $895 \mathrm{~K}$. A further decrease accurs at $995 \mathrm{~K}$, but an increase is seen at $1125 \mathrm{~K}$ with respect to calcination at $995 \mathrm{~K}$. For the $\mathrm{Co}(1.6) \mathrm{Mo}(2.5)$ catalysts the trend is the same, but not as pronounced. The highest loading (Co(4.1)Mo(2.5)) catalysts display an increase in activity when the temperature of calcination is raised from 785 to $895 \mathrm{~K}$. The activity becomes fairly constant at higher calcination temperatures. The order of activity per gram catalyst is reversed upon calcination above $895 \mathrm{~K}$, where the highest loading catalyst becomes more active than the lowest loading catalyst. 


\section{DISCUSSION}

$\underline{\mathrm{Mo} / \mathrm{Al}_{2}} \underline{\mathrm{O}}_{3}$

Loss of $\mathrm{MoO}_{3}$ is found by TPR [18] for catalysts calcined at $1125 \mathrm{~K}$. Surprisingly, mainly the monolayer Mo species ("MoI") are lost while it is expected that the amount of multilayer $\mathrm{MoO}_{3}$ ("MoII") decreases more, since it has a weaker interaction with the support. However, this is explained by the loss of surface area which necessarily brings about a reduction of the amount of the highly disperse MoI species [18].

White TPS results indicate that sulfiding is not greatly affected, figure $3 b$ shows that the TON is somewhat smaller at calcination temperatures of 895 and $995 \mathrm{~K}$, as is also found by others [23]. However, the TON actually increases after calcination at $1125 \mathrm{~K}$, which suggests that the MoII species is more active than the MoI species. A higher dispersion of the sulfided MoII species is not likely in view of the smaller surface area. It is concluded that the increased activity is caused by a weaker interaction with the support of the sulfided species, as is confirmed by the finding that Mo catalysts are more active when supported on a more inert support e.g. carbon $[24,27]$. Moreover, it can be concluded that support interactions found in the oxidic catalyst may persist in the sulfided phase for $\mathrm{Mo} / \mathrm{Al}_{2} \mathrm{O}_{3}$ catalysts.

\section{$\underline{\mathrm{CO} / \mathrm{Al}_{2}}{ }_{2} \underline{\mathrm{O}}$}

The TON decreases at higher temperatures of calcination due to formation of nonsulfidable $\mathrm{CoAl}_{2} \mathrm{O}_{4}$ species [16]. The activities observed indicate that Co can be present as an HOS active surface phase different from inactive $\mathrm{CaAl}_{2} \mathrm{O}_{4}-1$ ike species, as has also been found by TPR [6], TPS [7] and NO adsorption [9].

TPS results indicate that not $\operatorname{Cog}_{9} S_{8}$ but another sulfided $C_{0}$ species is present [7], as was proposed earlier [4]. We suggest that a Cos-like phase is present, and also $\mathrm{Cog}_{8}$ at higher loadings. This is analogous to the oxidic $\mathrm{Co} / \mathrm{Al}_{2} \mathrm{O}_{3}$ cataiysts where a $\mathrm{CoO}$ surface phase is found and the thermodynamically more stable $\mathrm{CO}_{3} \mathrm{O}_{4}$ is formed at higher loadings $[6,7]$.

\section{$\underline{\mathrm{CO}-\mathrm{Mo} / \mathrm{Al}_{2}} \underline{\mathrm{O}}_{3}$}

It has recently been shown by TPR that the reducibility of $C_{0}$ is greatly affected by the presence of Mo [18]. Also from other techniques the conclusion that an interaction or even an interaction phase ("CoMoO") exists in oxidic $\mathrm{Co}-\mathrm{Mo}_{\mathrm{A}} \mathrm{Al}_{2} \mathrm{O}_{3}$ catalysts $[4,5,9,10,11,12,23,25,28]$ has been drawn. This "COMoO" phase might we 1 be the precursor for the CoMos phase in the CoMos model [8,9]. Moreover, TPS has shown that active $\mathrm{Co}-\mathrm{Mo}_{\mathrm{A}} \mathrm{A}_{2} \mathrm{O}_{3}$ catalysts are well sulfidable at low temperatures, where, of course, large structural rearrangements during sulfiding are unlikely $[17]$. 
It is reported that the activity of a $\mathrm{Co}-\mathrm{MO} / \mathrm{Al}_{2} \mathrm{O}_{3}$ catalyst depends on the calcination temperature [25]. $\mathrm{Co} / \mathrm{Al}_{2} \mathrm{O}_{3}$ catalysts are very sensitive to this parameter $[5,6]$. The results presented here show that the effect of a change of the calcination temperature depends strongly on the co content. It can be seen that as the temperature of calcination is raised there is a sharp drop in activity for catalysts with a low Co content, and a slight rise in activity at high co content. At intermediate Co loadings (such as used in [25]) the effect of raising the temperature of calcination is not so strong.

From figure $3 a$ it is apparent that the well known synergistic curve, with a maximum activity at a fixed co content, is only obtained for the lowest temperature of calcination. All other curves rise monotonously.

To investigate whether these results

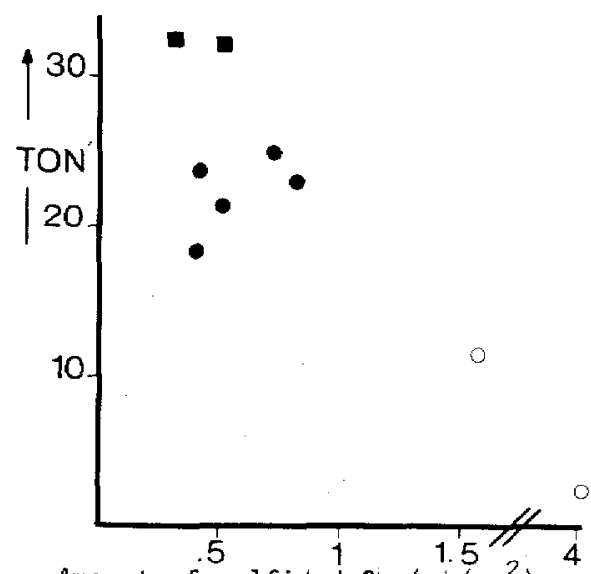

Amount of sulfided co $\left(\mathrm{at} / \mathrm{nm}^{2}\right)$ can be interpreted in terms of the amount of a single active phase a quantitative approach on the basis of turn-over numbers is chosen. The comos phase is many times more active than other phases present in the sulfided catalyst [21], so all activity can be ascribed to a single phase, which facilitates the interpretation of activity data. In figure 4 the TON' expressed per mole sulfided $C_{0}$ is plotted versus the amount of sulfided $C_{0}$ as determined from TPS experiments. Three regions of activity can be discerned:

FIGURE 4 Turn-over numbers for sulfided Co (mmol/mol.s) in $\mathrm{Co}-\mathrm{Mo} / \mathrm{Al}_{2} \mathrm{O}_{3}$ catalysts calcined at $785 \mathrm{~K}(0)$, at 895 or $995 \mathrm{~K}(\Theta)$ and at $1125 \mathrm{k}(\mathrm{O})$.

- high activity for catalysts calcined at $1125 \mathrm{~K}$

- moderate activity for catalysts calcined at 785-995 K, except for the catalysts with the highest $C_{0}$ loadings calcined at $785 \mathrm{~K}$

- low activity for the Co(1.6)Mo and Co(4.1)Mo catalysts calcined at $785 \mathrm{~K}$

The TON' values of the typical Co-Mo/Al ${ }_{2} \mathrm{O}_{3}$ catalysts 1 ie close together. This shows that indeed over a wide range of Co content and temperature of calcination the catalytic activity is caused by a single phase which contains sulfided $C_{0}$.

The low TON' values which underlie the low activity of the $785 \mathrm{~K}$ calcined catalysts, and thereby produce the typical synergistic curve, suggest that there is a 
difference in structure with all ather catalysts. The factor most likely responsible for this difference is the occurrence of $\mathrm{CO}_{3} \mathrm{O}_{4}$ crystallites, which are known to be present at higher co contents in the oxidic catalysts [18]. These are absent because of formation of $\mathrm{CoAl}_{2} \mathrm{O}_{4}-1$ ike species at higher temperatures of calcination $[5,6,18], \mathrm{CO}_{3} \mathrm{O}_{4}$ sulfides into $\mathrm{Co}_{9} \mathrm{~S}_{8}[4,7,8]$ with a low activity, which makes the TON' lower. However, it is not immediately clear why this should actually lower the HDS activity per gram of catalyst in the case of the catalyst with the highest co loading (figure 3a). Blocking of HDS sites is not likeiy since the active phase is more highly dispersed than the $\mathrm{Cog}_{8}$ crystallites. A more plausible explanation is that the amount of active phase is smaller because either the amount of oxidic precursor is smaller [8], or oxidic Co species sulfide into inactive $\mathrm{Cog}_{8}$, instead of a more active phase. Nucleation is here proposed to be the most difficult step in the formation of $\mathrm{CO}_{3} \mathrm{O}_{4}$ and $\mathrm{Co}_{9} \mathrm{~S}_{8}$ crystallites, but once nuclei are formed, growth is rapid at the expense of the active Co phase or precursor phase (e.g. CoMos or CoMoo).

The high TON' obtained for $\mathrm{Co}-\mathrm{Mo}_{\mathrm{O}} / \mathrm{Al}_{2} \mathrm{O}_{3}$ catalysts calcined at $1125 \mathrm{~K}$ shows that structural changes have taken place in the oxidic catalysts. For $\mathrm{Mo} / \mathrm{Al}_{2} \mathrm{O}_{3}$ catalysts also a higher TON was observed after calcination at $1125 \mathrm{~K}$ (this work) and the same interpretation seems applicable for the Co-Mo/Al ${ }_{2} \mathrm{O}_{3}$ catalysts: in accordance with earlier suggestions [18], BET results indicate a lower surface area. This causes a decrease in the amount of Mo in strong interaction with the support, both in the oxidic- and the sulfided state. Because the support interaction of the remaining active phase is weaker, it is a more active species. This is in accordance with the result that on a more inert carrier (carbon) a higher TON is obtained for a Co-Mo/C catalyst (TON = ca $55 \mathrm{mmol}$ thiophene/mol Co.s, calculated from data published by Duchet et al. [24]. TPS shows that even after calcination at high temperature sulfidable Mo- and Co species are present [17]. It is therefore concluded that the active species is structurally similar to the phase obtained at lower temperatures of calcination. I.e. the activity of the CoMoS phase depends on the interaction with the support, as corroborated by findings of $\mathrm{Co}-\mathrm{Mo} / \mathrm{C}$ [24].

It was found that after sulfiding at higher temperatures a "CoMoS II" phase is formed with a higher TON for HDS [26]. We can not yet prove that CoMoS II is identical with the phase formed after calcination at $1125 \mathrm{~K}$, but similar structural characteristics have been proposed. Furthermore, the higher activity of CoMoS II is also attributed to a weaker active phase-support interaction [26].

Further research is necessary to make full use of the higher TON obtained after more rigorous pretreatments, in order to produce catalysts with higher rates of HOS per gram catalyst. 


\section{REFERENCES}

1 R. Thomas, V.H.J. de Beer and J.A. Moulijn, Bull. Soc. Chim. Belg., 90 (1981) 1349.

2 P. Arnoldy, J.C.M. de Jonge, O.J. Wimmers and J.A. Moulijn, to be published.

3 P.Arnoldy, J.A.M. van den Heijkant, G.D. de Bok and J.A. Moulijn, J. Catal. 92 (1985) 35 .

4 K.S. Chung and F.E. Massoth, J. Catal., 64 (1980) 332.

5 K.S. Chung and F.E. Massoth, J. Catal., 64 (1980) 320.

6 P. Arnoldy and J.A. Moulijn, J. Catal., 93 (1985) 38.

7 P. Arnoldy, J.L. de Booijs, B. Scheffer and J.A. Moulijn, J. Catal, 96 (1985) 122.

8 C. Wivel, B.S. Clausen, R. Candia, S. Mdrup and H. Topsøe, J. Catal. 87 (1984) 497.

9 N.Y. Topsqe and H. Topsøe, J. Catal., 77 (1982) 293.

10 F. Delannay, E.N. Haeussler and B. Deimon, J. Catal., 66 (1980) 469.

11 M. LoJacono, A. Cimino and G.C.A. Schuit, Gaz. Chim. Ital., 103 (1973) 83.

12 P. Gajardo, P. Grange and B. Delmon, J. Catal., 63 (1980) 201.

13 T.A. Pecoraro and R.R. Chianelli, J. Catal., 67 (1981) 430.

14 V.H.J. de Beer, J.C. Duchet and R. Prins, J. Catal., 72 (1981) 369.

15 H. Topsøe and B.S. Clausen, Catai. Rev.-Sci. Eng., 26 (1984) 395.

16 V.H.J. de Beer, C. Bevelander, T.H.M. van Sint Fiet, P.G.A.J. Werter and C.H. Amberg, J. Catal., 43 (1976) 68.

17 B. Scheffer, J.C.M. de Jonge, P. Arnoldy and J.A. Moulijn, Bull. Soc. Chim. Belg., 93 (1984) 751.

18 P. Arnoldy, M.C. Franken, B. Scheffer and J.A. Moulijn, J. Catal, 96 (1985) 381.

19 V.H.J. de Beer, T.H.M. van Sint Fiet, J.F. Engelen, A.C. van Haandel, M.W.J. Wolfs, C.H. Amberg and G.C.A. Schuit, J. Catal., 27 (1972) 357.

20 F.E. Massoth and K.S. Chung, Proc. 7 th Int. Cong. Catal., Tokyo (1980) A44.

21 C. Wivel, R. Candia, B.S. Clausen, S. Mørup and H. Topsøe, J. Catal., 68 (1981) 453.

22 P. Arnoldy, F. Paap and J.A. Moulijn, to be published.

23 A. Morales, N.P. Martinez, J. Laine, F. Payen and J. Grimblot, Applied Catal., 6 (1983) 329.

24 J.C. Duchet, E.M. van Oers, V.H.J. de Beer and R. Prins, J. Catal., 80 (1983) 386.

25 R. Candia, N.Y. Topsøe, 8.S. Clausen, C. Wivel, R. Nevald, S. Morup and H. Topsøe, Proc. 4 th Int. Conf. Chemistry and Uses of Molybdenum, Golden, Colorado (1982), 374 .

26 R. Candia, O. Sørensen, J. Villadsen, N.Y. Topsøe, B.S. Clausen and H. Topsøe, Bul1. Soc. Chim. Belg., 93 (1984) 763.

27 J.P.R. Vissers, B. Scheffer, J.A. Moulijn, V.H.J. de Beer and R. Prins, submitted for publication.

$28 \mathrm{~N}-\mathrm{Y}$. Topsфe and H. Topsфe, J. Catal., 75 (1982) 354.

29 G. Delvaux, P. Grange and B. Delmon, J. Catal., 56 (1979) 99. 